\title{
Customers Literacy on Islamic House Financing Products
}

\section{Indah Bidari, A. Jajang W. Mahrí, and Rida Rosida}

Economics and Islamic Finance Department, Universitas Pendidikan Indonesia, Jl. Dr. Setiabudhi No. 229 Kota Bandung

\section{Abstract}

Sharia financial literacy is a person's understanding of the products of Islamic financial institutions in order to improve the ability and willingness of someone to take advantage of products in the Islamic financial institutions as one solution for the needs of economy. This study aims to obtain a picture of how the level of literacy of Islamic house financing products in Islamic house financing customers with various kinds of contracts (aqd) used in sharia house financing. This research uses quantitative descriptive method. The population in this study are sharia financing customers which amounted to 150 people and a sample of 80 people with purposive sampling technique. Instrument in

Corresponding Author: Indah Bidari

indah.bidari95@student.upi.edu

Received: 10 February 2019

Accepted: 14 March 2019

Published: 28 March 2019

Publishing services provided by Knowledge E

(c) Indah Bidari et al. This article is distributed under the terms of the Creative Commons

Attribution License, which permits unrestricted use and redistribution provided that the original author and source are credited.

Selection and Peer-review under the responsibility of the ICIEBP Conference Committee.

\section{G OPEN ACCESS} this study using questionnaires. The results of this study indicate the level of customer literacy on shariah house financing products and kinds of contracts (aqd) used in sharia house financing in different Islamic banks are in good category, although there are some indicators are in good enough category.

Keywords: Islamic Financial Literacy, Murabaha, Musharakah Mutanaqisah, Istisna, Sharia house financing

\section{Introduction}

Financial literacy is an important element of economic and financial stability, both for the individual and the economy. Financial literacy is particularly important for the young, as they face financial decisions that can have important consequences throughout their life. The younger generations increased responsibility requires them to have the knowledge to make sound financial decisions early on. One such decision is the house financing, because house is one of the important needs for humans, especially for those who have a family. So the level of housing needs increases with increasing population (www.bi.go.id/kajian/documents, 2011).

Based on data from the Bureau Statistics Center (BPS) in 2016, out of 240 million Indonesian population consisting of 61 million households, a total of $22 \%$ or as many as 
13.6 million households do not have a house. Until 2017, the level of housing needs for Indonesian people is still high. These problems can be seen in Figure 1:

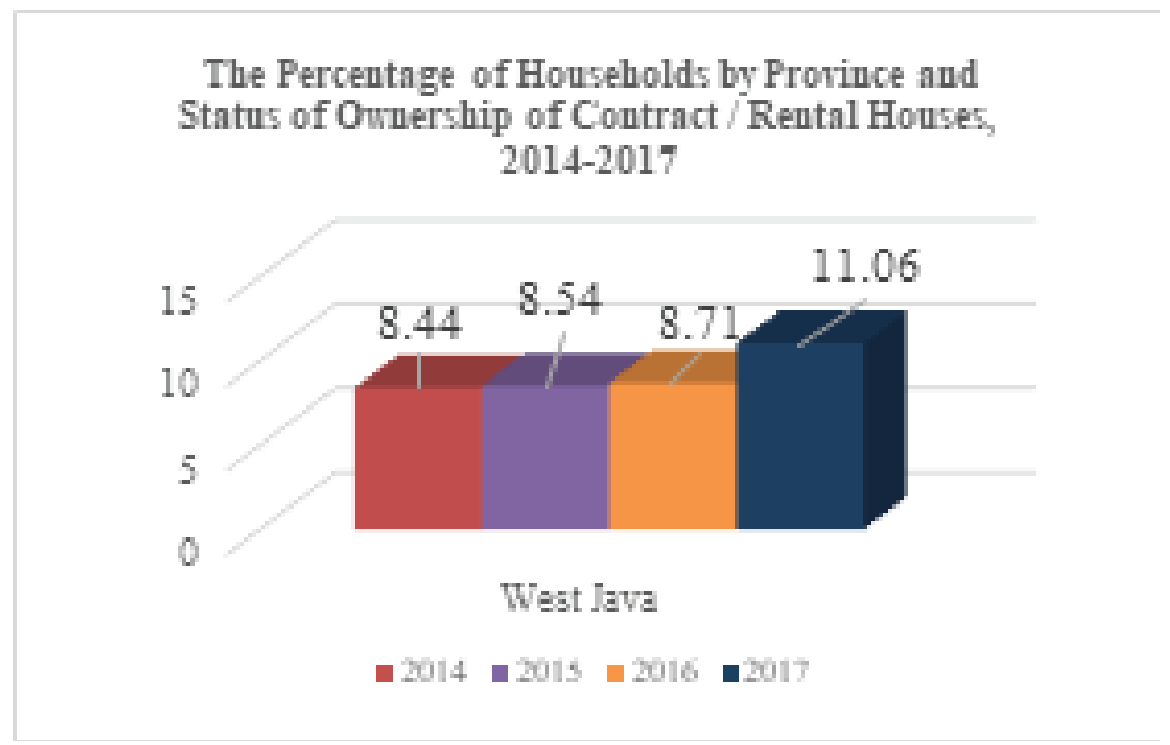

Figure 1: The Percentage of Households by Province, Type, of Region and Status of Ownership of Contract/Rental Houses, 2014-2017 (Source: Bureau Statistics Center (2017)).

Based on Figure 1, in 2014, the number of people who rented houses in West Java was $8.44 \%$ and rise to $11.06 \%$ in 2017 . This relatively high percentage, because because the effort to get a house at this time is not an easy thing. The increasingly limited amount of land makes house prices more expensive so that it is impossible to reach for the public with minimum income.

That means financial literacy is especially important because of the various reasons such as the increasing complexity of financial products and services which are also accessible from a growing number and type of providers. Due to the increase in number and complexity of the financial products and services, individuals are also being asked to take more responsibility for important financial decisions and a large numbers of consumers are entering financial markets for the first time, both because income is growing in developing countries and because new financial institutions, such as microfinance providers, and new technologies, such as branchless banking, which have made it easier for consumers to participate in financial market (Miller, Margaret, \& al, 2009).

\section{Literature Review}

Otoritas Jasa Keuangan defines financial literacy as the ability to understand knowledge and skills to manage financial resources to achieve prosperity. It can be concluded that 
with the existence of financial literacy, customers and the public do not only know sharia financial institutions or their products, but they are also able to understand and use products and services in Islamic financial institutions as one of the steps in changing people's behavior in managing finances with the system. Islam for the sake of achieving economic prosperity.

According to the Organization for Economic Co-operation and Development or OECD (Atkinson \& Messy, 2011) in a journal written by Oman \& Lilis (2015) explained that financial literacy as a combination of awareness, knowledge, skills, attitudes and behaviors needed to make financial decisions which is good and ultimately achieves good individual financial conditions.

In Islam, the purpose of Allah SWT instructs mankind to pay attention to all that is eaten is so that humanity understands how food affects the human body. Everything that is eaten is not only in the form of food, but food or material that humans use to survive in the world. This can also be attributed to the qouliyah hadith of the Prophet Muhammad SAW narrated by Ibn Majah, namely:

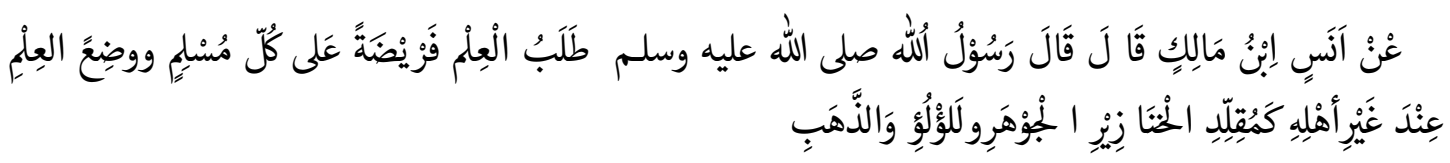

Meaning: "From Anas bin Malik he said, Rasulullah SAW. said: Searching for knowledge is obligatory for every Muslim, giving knowledge to people who are not experts like those who carry pigs with gems, pearls or gold" (HR Ibn Majah)

According to OJK, in 2013 the level of financial literacy in Indonesia only reached $21.8 \%$. Meanwhile the level of inclusion of financial services products was only $59.7 \%$, lower than other countries in Southeast Asia. So there is a need to measure the level of individual literacy so that the economy grows in Indonesia.

Based on the definition and concept of financial literacy above, it can be explained through the concepts that will be examined in the study so that it can be used as a guideline to avoid misunderstanding in interpreting the problems raised in the research conducted. The variables in this study are:

1. Islamic Financial Literacy

2. Understanding customers of Islamic banks

3. Understanding customers of Islamic home financing products

4. Understanding of customers on the use of contracts in Islamic home financing 
5. Understanding of customers about the benefits or advantages of various uses of sharia home financing contracts

6. Understanding of customers about the risks or weaknesses of Islamic home financing

7. Understanding customers of the rights as sharia home financing customers

8. Understanding of customers on obligations as sharia home financing customers

\section{Methodology}

This research is using quantitative descriptive method. The object of this research is home financing customer in Bank Syariah Mandiri, Bank Muamalat and BTN Syariah. The object in this research is Islamic Commercial Banks that apply murabahah contracts, mutanaqisah musyarakah contracts, and istishna contracts' that is Bank Syariah Mandiri, Bank Muamalat, and Bank BTN Syariah with a population of 100 people. Sampling techniques using a purposive sampling approach quota sampling is obtained as many as 80 respondents.

\section{Result}

Based on the results of research in the field, known general description of the characteristics of respondents are as follows:

TABLE 1: Characteristics of Respondents by Age (Source: Research Results (2017)).

\begin{tabular}{|l|l|}
\hline No & \multicolumn{1}{|c|}{ Age } \\
\hline 1 & Age $29-32$ \\
\hline 2 & Age $33-36$ \\
\hline 3 & Age $37-40$ \\
\hline 4 & Age $41-44$ \\
\hline 5 & Age $45-48$ \\
\hline 6 & Age $46-49$ \\
\hline 7 & Age $50-53$ \\
\hline & Total \\
\hline
\end{tabular}

$\begin{gathered}\text { Frequency } \\ \text { (person) }\end{gathered}$
9
18
29
9
8
4
3
80 person

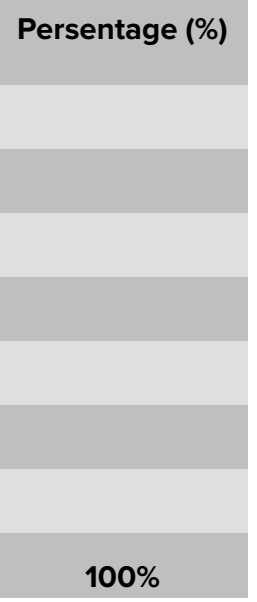

Based on the findings of the field that the the age of respondents ranges from 37 to 40 more than other age ranges, followed by the age range of 33-36 which is the 
second most age range. This is because according to BPS data, the highest composition of labor based on working age in Indonesia is the age range 35-39. Meanwhile, the age range of 50-53 is the lowest age range because one of the procedures for applying for sharia home financing with a maximum age of 55 years so that it is impossible for customers over 50 years of age to make sharia home financing transactions.

TABLE 2: Characteristics of Respondents by Job (Source: Research Results (2017)).
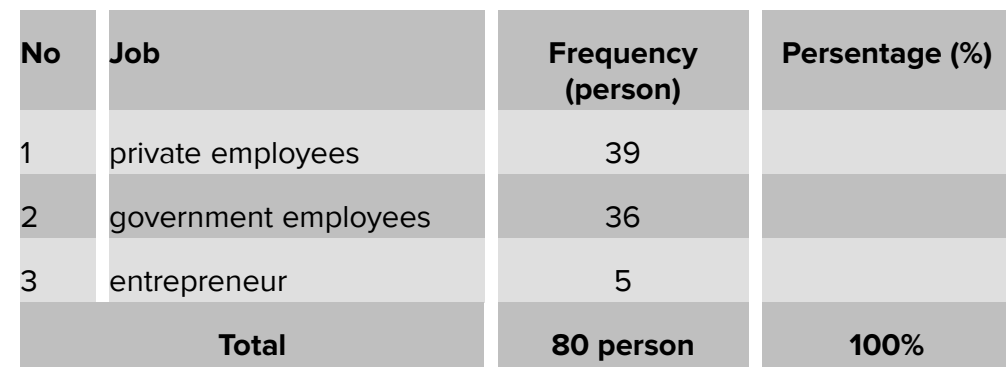

Based on the findings of the field that more respondents with the work of private employees and civil servants, this happened when the authors offered questionnaires in the field of more private employees and civil servants that the authors found.

Customer literacy on Syariah home financing products can be explained from the results of the analysis of each questionnaire answer from the customers who filled it. This questionnaire was distributed to 80 respondents with a total of 34 questions which referred to several predetermined indicators. The indicators in question are: a) Understanding customers of Islamic banks; b) Understanding of customers on Sharia home financing products; c) Understanding of customers on the use of contracts on sharia home financing products; d) Understanding of customers about the benefits or advantages of sharia home financing; e) Understanding of customers about the risks or weaknesses of sharia home financing; f) Understanding the customer of the right as a sharia home financing customer; g) Understanding of the client's obligations as a sharia home financing customer.

Based on Table 7 shows that the condition of the understanding of the client's obligations as a sharia home financing customer and the understanding of customers about the benefits or advantages of sharia home financing are already good enough and it means other than that based on the findings of the field that almost most or $85 \%$ of customer have already understand all the obligations that must be fulfilled and the benefits of sharia home financing that have been felt. 
TABle 3: Overview Spiritual Welfare Mustahik (Source: Research Results (2017)).

\begin{tabular}{|l|l|l|l|}
\hline No & $\begin{array}{l}\text { Indicators } \\
\text { Understanding customers of Islamic } \\
\text { banks }\end{array}$ & 80 & Conclusion \\
\hline 2 & $\begin{array}{l}\text { Understanding of customers on } \\
\text { Sharia home financing products }\end{array}$ & 76.5 & Good Enough \\
\hline 3 & $\begin{array}{l}\text { Understanding of customers on the } \\
\text { use of contracts on sharia home } \\
\text { financing products }\end{array}$ & 69.5 & Good \\
\hline 4 & $\begin{array}{l}\text { Understanding of customers about } \\
\text { the benefits or advantages of sharia } \\
\text { home financing }\end{array}$ & 81.8 & Good \\
\hline 5 & $\begin{array}{l}\text { Understanding of customers about } \\
\text { the risks or weaknesses of sharia } \\
\text { home financing }\end{array}$ & 74.16 & Good Enough \\
\hline 6 & $\begin{array}{l}\text { Understanding the customer of the } \\
\text { right as a sharia home financing } \\
\text { customer }\end{array}$ & 78 & Good Enough \\
\hline 7 & $\begin{array}{l}\text { Understanding of the client's } \\
\text { obligations as a sharia home } \\
\text { financing customer }\end{array}$ & $\mathbf{7 9 . 8}$ & Good Enough \\
\hline
\end{tabular}

\section{Conclusion}

Based on research results, an overview of customer literacy regarding Islamic home financing is good enough. it is good news that must be maintained or maybe done better so that the existence of Islamic banks and their products can always have good value in the eyes of everyone.

[1] Abdullah, M. A., \& Anderson, A. (2015). Islamic Financial Literacy among Bankers in Kuala Lumpur. Journal of Emerging Economies and Islamic Research.

[2] Ahmad, N. W., Mawar, M. Y., \& Ripain, N. (2016). FINANCIAL LITERACY OF YOUTH: A CASE STUDY OF ISLAMIC BANKING AND FINANCE STUDENTS IN KOLEJ UNIVERSITI ISLAM ANTARABANGSA SELANGOR.

[3] Atkinson, A., \& Messy, F.-A. (2011). Assessing financial literacy in 12 countries: an OECD/INFE international pilot exercise. Journal of Pension Economic and Finance.

[4] Er, B., \& Mutlu, M. (2017). Financial Inclusion and Islamic Finance: A Survey of Islamic Financial Literacy Index. International Journal of Islamic Economics And Flnance Studies. 
[5] Ergun, K. (2017). Financial literacy among university students: A study in eight European countries.

[6] LUSARDI, A. (2015). Financial Literacy Skills for the 21st Century: Evidence from PISA.

[7] Maamor, S., Rahman, N. L., \& Hamed, A. B. (2016). Determinants of Islamic Home Financing Product Selection among Lower Income Group in Kuala Lumpur, Malaysia. International Journal of Economics and Financial Issues.

[8] Miller, Margaret, \& al, e. (2009). The Case for Financial Literacy in Developing Countries: Promoting Access to Finance by Empowering Consumers. World Bank, DFID, OECD e CGAP, http://www. oecd. org/dataoecd/35/32/43245359. pdf.

[9] Naseem, T. M. (2014). Islamic Housing Finance: Opportunity \& Challenges. World Bank/IFC 6th Global Housing Finance Conference, Washington DC.

[10] Razak, D. A. (2011). Consumers' perception on Islamic home financing: Empirical evidences on Bai Bithaman Ajil (BBA) and diminishing partnership (DP) modes of financing in Malaysia.

[11] Rusmana, O., \& Ardianti, L. (2015). Analisis Perbedaan Literasi Keuangan Masyarakat Anggota Credit Union dengan Anggota Baitul Tamwil. 